\title{
Shunt Active Power Filter Based on P-Q Theory with Multilevel Inverters for Harmonic Current Compensation
}

\author{
Suhendar ${ }^{1}$, Teguh Firmansyah $^{{ }^{2}}$, Alief Maulana ${ }^{3}$, Zuldiag $^{4}$, Vektor Dewanto ${ }^{5}$ \\ ${ }^{1,2,3,4}$ Department of Electrical Engineering, University of Sultan Ageng Tirtayasa, Cilegon 42435 \\ ${ }^{5}$ Computer Science Department, Bogor Agricultural University, Bogor, Indonesia \\ ${ }^{*}$ Corresponding author, e-mail: teguhfirmansyah@untirta.ac.id
}

\begin{abstract}
A shunt active power filter based on $P-Q$ theory combined with high pass filters (HPFs) for harmonic-current compensation was proposed in this paper. A dual level H-bridge inverter (DLHI) and clamp diode multilevel inverter (CDMI) as inverters was used. The proposed active power filter was applied to 3-phase power system with $220 \mathrm{~V}$ voltage and $50 \mathrm{~Hz}$ frequency. the simulation model was constructed by using Simulink MATLAB. The results show that the proposed active power filter with CDMI produces lower total harmonic distortion (THD) than the active power filters with DLHI. Additionally, the proposed shunt active power filter has lower THD compared with other types of active power filters.
\end{abstract}

Keywords: CDMI, DLHI, inverter, simulink MATLAB, THD

Copyright @ 2017 Universitas Ahmad Dahlan. All rights reserved.

\section{Introduction}

The power quality is determined by voltage swell, voltage sag, flicker, voltage interruption, negative and zero sequence components, voltage and current harmonics [1,2]. The use of non-linear load can increase a harmonic current [3]. The harmonic current also cannot contribute to the active power and need to be eliminated to enhance the power quality [4]. Recent efforts have been made to improve the power quality by reducing harmonic current based on active power filters [5]. A three-phase active power filters was proposed by [6]. This active power filter is controlled by the $P-Q$ theory, the notch instantaneous method, and the positive sequence method. A pulse width modulation (PWM) was used as an inverter. This research shows that a notch instantaneous method can reduce a har monic current with the value of total harmonic distortion (THD) from $19.76 \%$ down to $5.58 \%$. Furthermore, a positive sequence method can reduce THD to $12.76 \%$, THD depression does not occur significantly. Compared with the previous methods, the P-Q theory can reduce THD to $3.54 \%$. The THD result is lower than those of the notch instantaneous and positive sequence methods.

A single-phase shunt active filter with a fuzzy controller and a PI controller for harmonic mitigation was proposed by [7]. This active power filter was applied to $230 \mathrm{~V}$, and $50 \mathrm{~Hz}$ power systems. The fuzzy controller was reduced THD significantly in comparison with a conventional PI controllers. The dual-level inverter with a PI controller has THD of $8.39 \%$, which is higher than dual-level inverter with a fuzzy controller with THD of $5.68 \%$. In the case of a multi-level inverter, the PI controller has $7.10 \%$ and it is also higher than multilevel inverter with a fuzzy controller with THD $4.47 \%$. Ref [8] proposed a 3-level (NPC) shunt active power filter based on $\mathrm{P}-\mathrm{Q}$ theory combined with a fuzzy controller for harmonic-current compensation. The simulation results show that the effectiveness of the designed shunt active filter based on PWM fuzzy logic controllers. THD is reduced after compensation to $2.12 \%$.

In this paper, we propose a shunt active power filter based on $\mathrm{P}-\mathrm{Q}$ theory combined with high pass filters (HPFs) for harmonic-current compensation. In this research, we used a dual level $\mathrm{H}$-bridge inverter (DLHI) and clamp diode multilevel inverter (CDMI) as the inverters. We applied the proposed active power filter to 3-phase $220 \mathrm{~V}$ and $50 \mathrm{~Hz}$ power systems. The superiority of $\mathrm{P}-\mathrm{Q}$ theory includes the capability of working instantaneously and in time domain [9-11]. The P-Q theory is applied in 3-phase [12]. Hence, P-Q theory considers the 3phase as a unit, not a superposition or sum of three single-phase circuits [13]. Therefore, the P- 
$Q$ theory is flexible in designing shunt active power filters combined with a multilevel inverter for harmonic-current compensation. The design methodology is detailed in the following sections. Section 1 describes the state of the art solutions. Section 2 describes the $P-Q$ theory instantaneous power. Furthermore, the performance of the proposed shunt active power filter is reported in Section 3. Finally, Section 4 concludes this research.

\section{Research Method}

As shown in Figure 1, we propose a shunt active power filter based on $\mathrm{P}-\mathrm{Q}$ theory combined with high pass filters (HPFs) for harmonic-current compensation. We applied the proposed active power filter to 3-phase power system with a voltage of $220 \mathrm{~V}$ and frequency of $50 \mathrm{~Hz}$. A flow chart for calculation of compensating current shown in Figure 2. A system wih nonlinear load was constructed using Simulink MATLAB.

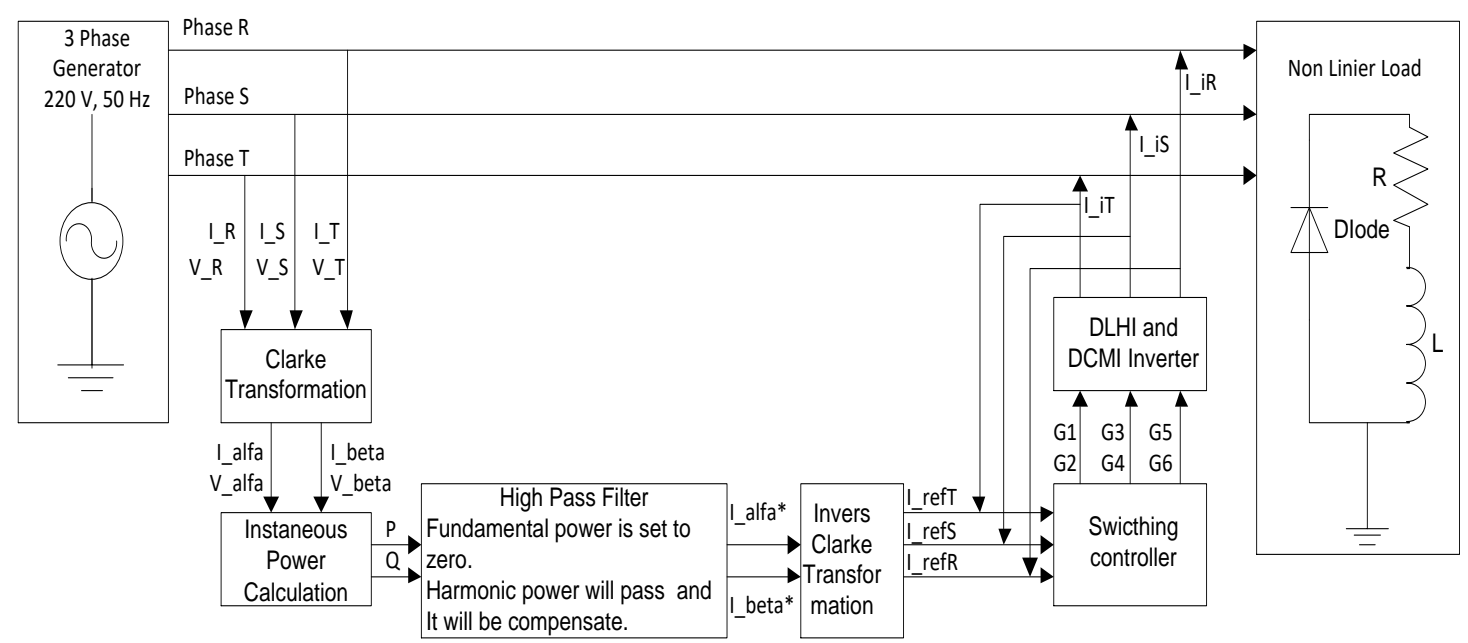

Figure 1. Proposed a shunt active power filter with CDMI and DLHI inverter

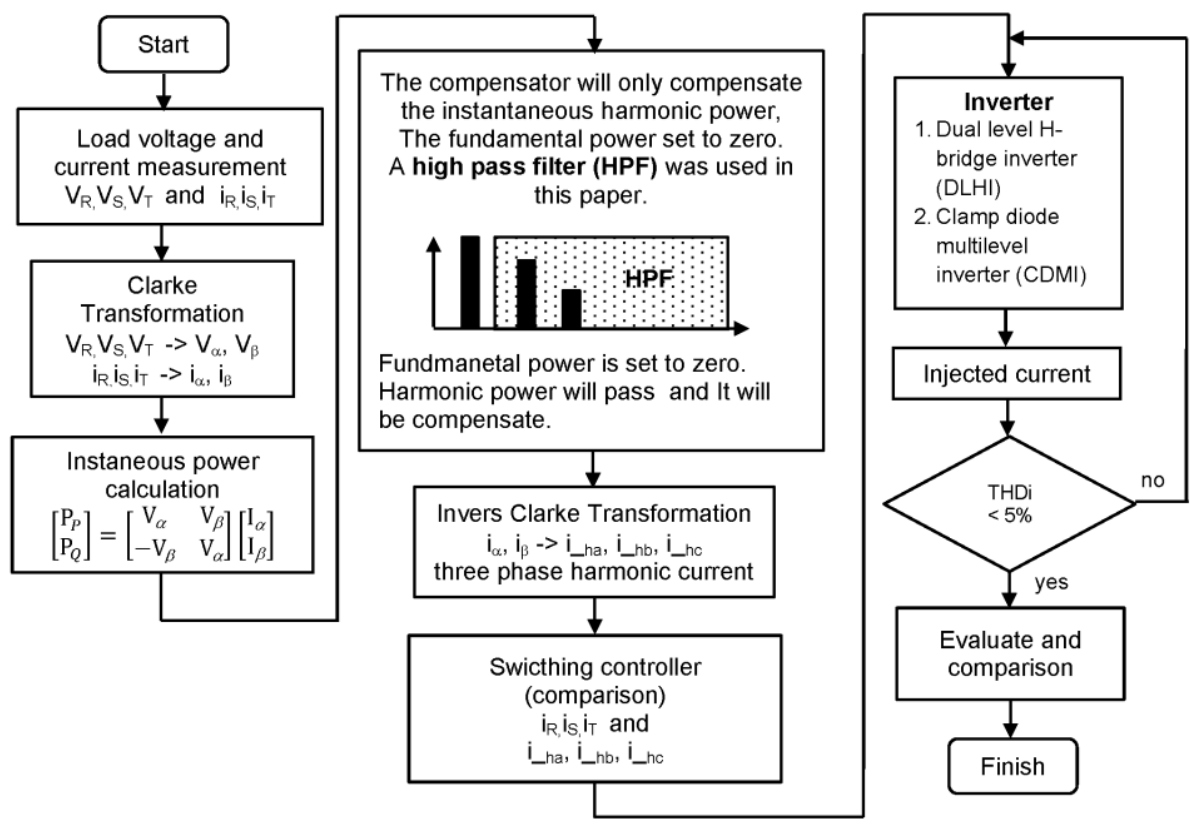

Figure 2. A flow chart for calculation of compensating current 
According to IEEE-519 standard, the total harmonic distortion (THD) is given by [14]:

$$
T H D=\frac{\sqrt{\sum_{h=2}^{\infty} I_{h R M S}^{2}}}{I_{R M S}}
$$

where $I_{R M S}$ is the effective value of fundamental current and $I_{h R M S}$ is the effective value of harmonic current. Filter is not only reduce interference but also reduce harmonics power [15], [16-18]. To reduce the THD, this study was used the $P-Q$ theory. The $P-Q$ instantaneous power theory was introduced by Akagi, et al $[13,14]$. The $P-Q$ theory consists of Clark Transformation as shown in Figure 2. The three-phase current of $\mathrm{I}_{R}, \mathrm{I}_{S}, \mathrm{I}_{T}$ and voltage $\mathrm{V}_{R}, \mathrm{~V}_{S}, \mathrm{~V}_{T}$ in R-S-T coordinates transform to $\alpha-\beta$ coordinates using Equation (2) and (3) [14].

$$
\begin{aligned}
& {\left[\begin{array}{l}
\mathrm{I}_{\alpha} \\
\mathrm{I}_{\beta}
\end{array}\right]=\sqrt{\frac{2}{3}}\left[\begin{array}{ccc}
1 & -\frac{1}{2} & \frac{1}{2} \\
0 & \frac{\sqrt{3}}{2} & -\frac{\sqrt{3}}{2}
\end{array}\right]\left[\begin{array}{l}
\mathrm{I}_{R} \\
\mathrm{I}_{S} \\
\mathrm{I}_{T}
\end{array}\right]} \\
& {\left[\begin{array}{l}
\mathrm{V}_{\alpha} \\
\mathrm{V}_{\beta}
\end{array}\right]=\sqrt{\frac{2}{3}}\left[\begin{array}{ccc}
1 & -\frac{1}{2} & \frac{1}{2} \\
0 & \frac{\sqrt{3}}{2} & -\frac{\sqrt{3}}{2}
\end{array}\right]\left[\begin{array}{l}
\mathrm{V}_{R} \\
\mathrm{~V}_{S} \\
\mathrm{~V}_{T}
\end{array}\right]}
\end{aligned}
$$

After the Clarke transformation of current and voltage. It's followed by instaneous power calculation. Real power and reactive powers are calculated with (4):

$$
\left[\begin{array}{l}
\mathrm{P} \\
\mathrm{Q}
\end{array}\right]=\left[\begin{array}{cc}
\mathrm{V}_{\alpha} & \mathrm{V}_{\beta} \\
-\mathrm{V}_{\beta} & \mathrm{V}_{\alpha}
\end{array}\right]\left[\begin{array}{l}
\mathrm{I}_{\alpha} \\
\mathrm{I}_{\beta}
\end{array}\right]
$$

Thus:

$P=\bar{P}+\tilde{P}$

$Q=\bar{Q}+\tilde{Q}$

where

$\bar{P}=$ instantaneous real power $\mathrm{P}$ due to the fundamental component;

$\tilde{P}=$ instantaneous harmonic real power $\mathrm{P}$ due to the harmonic component;

$\bar{Q}=$ instantaneous reactive power $Q$ due to the fundamental component;

$\tilde{Q}=$ instantaneous harmonic reactive power $Q$ due to the harmonic component;

In this paper, a high pass filter (HPF) was used. The real power is set to zero and an instantaneous reactive power is set into opposite vectors in order to cancel the reactive component of the line current. The compensator will only compensate the instantaneous reactive power.

$$
\left[\begin{array}{l}
\mathrm{I}_{c \alpha} \\
\mathrm{I}_{c \beta}
\end{array}\right]=\frac{1}{\mathrm{~V}_{\alpha}{ }^{2}+\mathrm{V}_{\beta}{ }^{2}}\left[\begin{array}{cc}
\mathrm{V}_{\alpha} & \mathrm{V}_{\beta} \\
\mathrm{V}_{\beta} & -\mathrm{V}_{\alpha}
\end{array}\right]^{-1}\left[\begin{array}{l}
-\tilde{P} \\
-\mathrm{Q}
\end{array}\right]
$$

To get the reference current harmonics, the harmonic currents in the bi-phase system to be transformed by Inverse Clarke Transformation of $\alpha-\beta$, which is given by Equation $(6)[13,14]$

$$
\left[\begin{array}{l}
\mathrm{I}_{-} h a \\
\mathrm{I}_{-} h b \\
\mathrm{I}_{-} h c
\end{array}\right]=\sqrt{\frac{2}{3}}\left[\begin{array}{cc}
1 & 0 \\
-\frac{1}{2} & \frac{\sqrt{3}}{2} \\
-\frac{1}{2} & -\frac{\sqrt{3}}{2}
\end{array}\right]\left[\begin{array}{l}
\mathrm{I}_{c \alpha} \\
\mathrm{I}_{c \beta}
\end{array}\right]
$$

The controller is used for generating pulses as the input of the inverter by comparing the value of the reference current and the current measured.

The last circuit is an inverter. Figure 3 and Figure 4 show the MATLAB simulation of dual level H-bridge inverter (DLHI) dan clamp diode multilevel inverter (CDMI), respectively. Table 2 shows the parameter of simulation and Table 3 shows the comparing reference current and the current measured. 
Table 2. Parameter of Shunt Active Power Filter Simulation

\begin{tabular}{cc}
\hline $\begin{array}{c}\text { Parameter } \\
\text { Power system }\end{array}$ & $\begin{array}{c}\text { Value } \\
\text { Three Phase }\end{array}$ \\
\hline Vs & $220 \mathrm{~V}$ \\
Frequency & $50 \mathrm{~Hz}$ \\
RI & $100 \Omega$ \\
LI & $5 \mathrm{H}$ \\
Rf & $10 \Omega$ \\
Lf & $5 \mathrm{H}$ \\
\hline
\end{tabular}

Table 3. The Comparing Reference Current and the Current Measured

\begin{tabular}{ccc}
\hline \multirow{2}{*}{ Condition } & \multicolumn{2}{c}{ State } \\
& G1 & G2 \\
\hline $\mathrm{I}_{h a} \geq \mathrm{I}_{R}$ & 1 & 0 \\
$\mathrm{I}_{h a}<\mathrm{I}_{R}$ & 0 & 1 \\
$\mathrm{I}_{h b} \geq \mathrm{I}_{S}$ & 1 & 0 \\
$\mathrm{I}_{h b}<\mathrm{I}_{S}$ & 0 & 1 \\
$\mathrm{I}_{h c} \geq \mathrm{I}_{T}$ & 1 & 0 \\
$\mathrm{I}_{h c}<\mathrm{I}_{T}$ & 0 & 1 \\
\hline
\end{tabular}

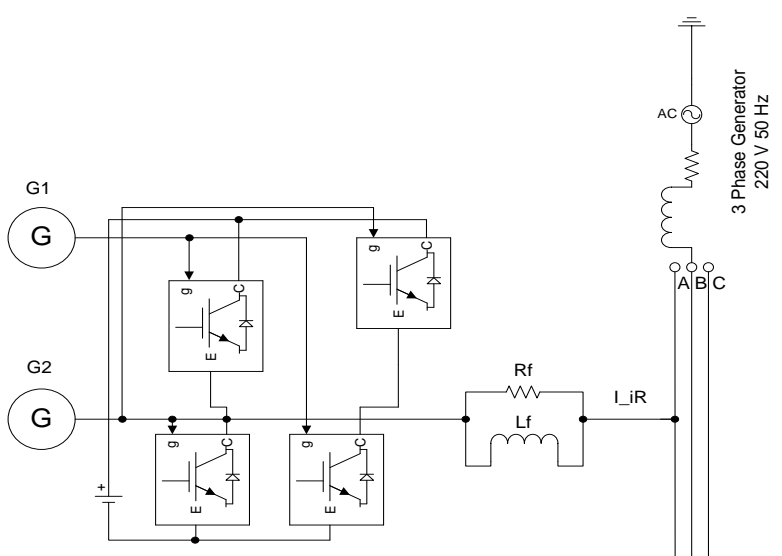

G3
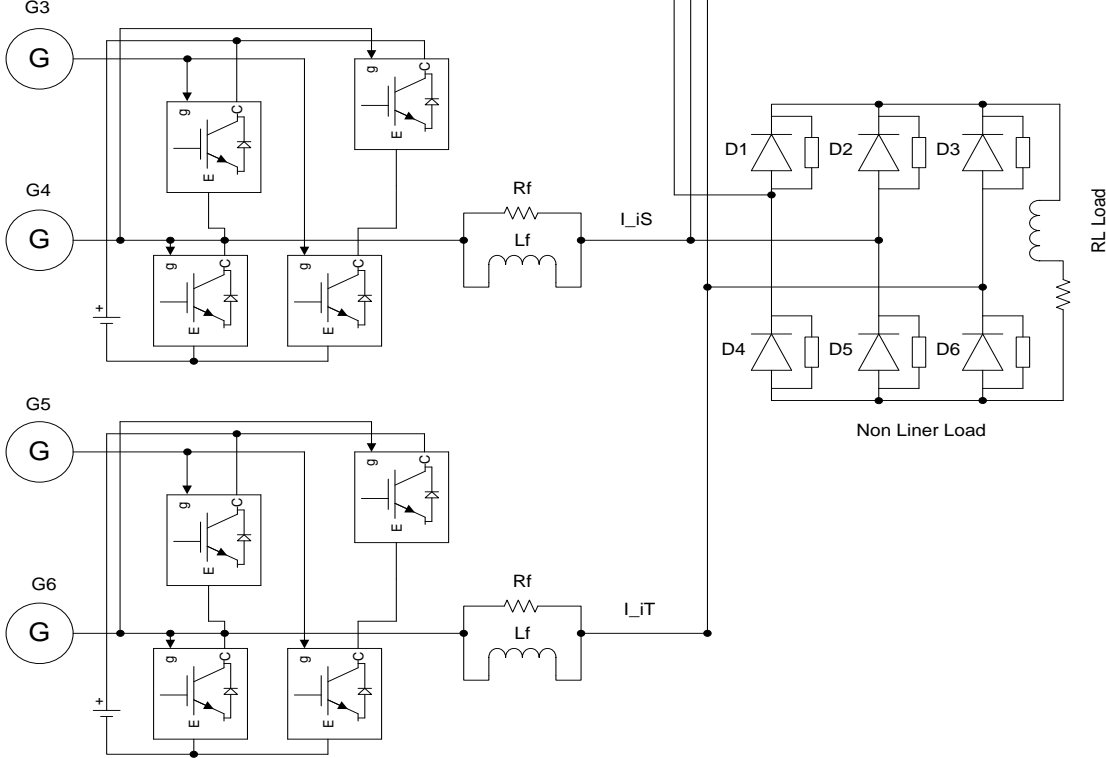

Figure 3. Dual level H-bridge inverter (DLHI) [This Research: Inverter Model 1] 


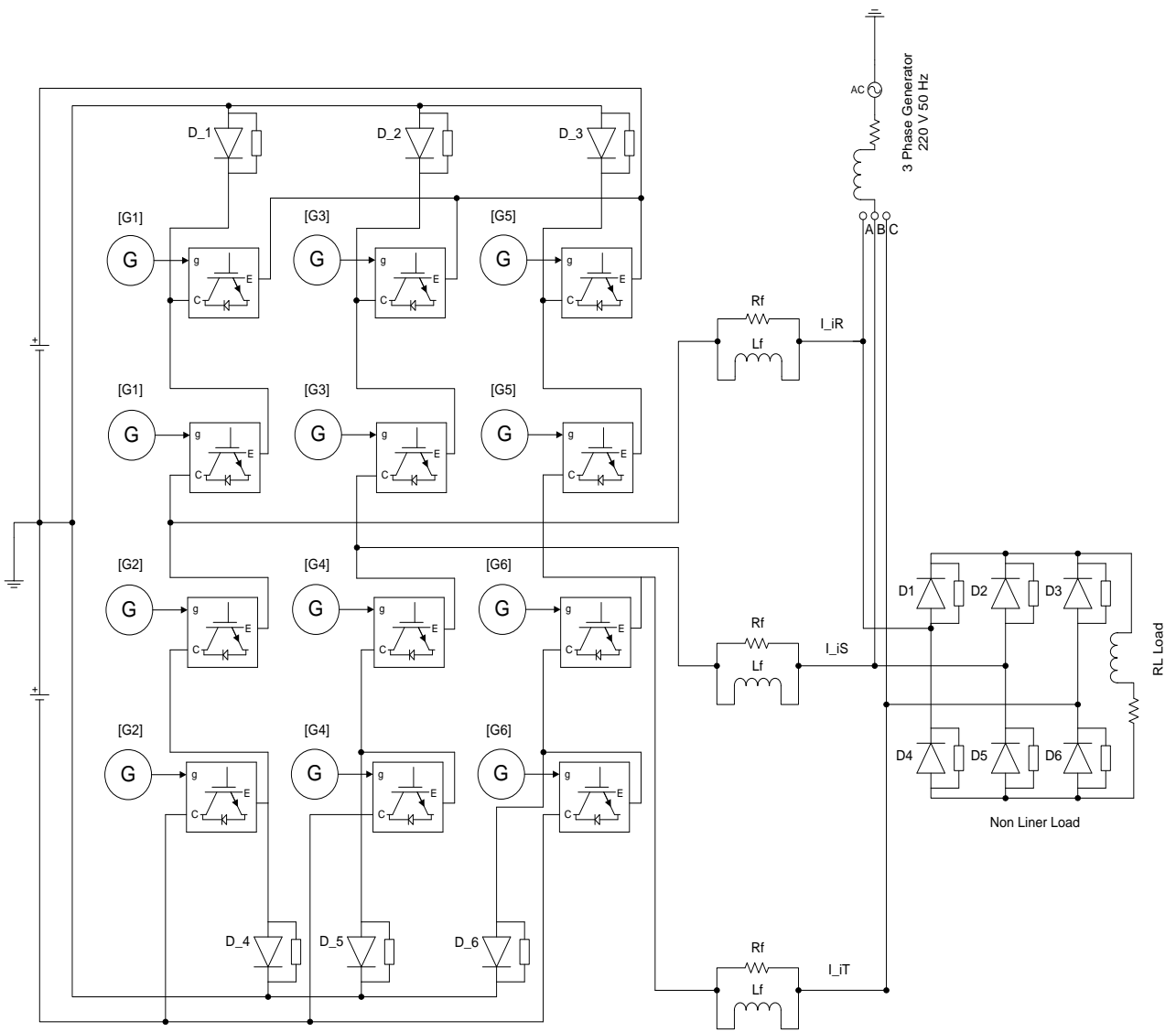

Figure 4. Clamp diode multilevel inverter (CDMI) [This Research: Inverter Model 2]

\section{Result and Analysis}

The performances of the proposed shunt active power were explained in this section. Section 3.1 shows the performance of three-phase power system with nonlinear load without an active filter. Furthermore, section 3.2 and section 3.3 was explained shunt active power filter with dual level $\mathrm{H}$-bridge inverter (DLHI) and clamp diode multilevel inverter (CDMI), respectively.

\subsection{Performance the three phase power system with nonlinear load}

A system with nonlinear load as shown in Figure 3, and the THD before the shunt active filter operation has $28.41 \%, 27.08 \%$, and $28.35 \%$ for phase R, phase $\mathrm{S}$, and phase $\mathrm{T}$, respectively. It is shown that a nonlinear load was effected to increase the THD value.

Figure 5a. shows a three phases of current in transient condition and steady state condition. At the steady state condition, the Fourier Series approximations of $I_{R}$ current is shown in Figure 6 and the Equation of $I_{R}$ is given by:

$$
\begin{aligned}
I_{R}=2.6 \sin (\omega t) & +0.07 \sin \left(3 \omega t+230^{\circ}\right)+0.55 \sin \left(5 \omega t+145^{\circ}\right)+0.33 \sin \left(7 \omega t+56.4^{\circ}\right) \\
& +0.06 \sin \left(9 \omega t+163.7^{\circ}\right)
\end{aligned}
$$




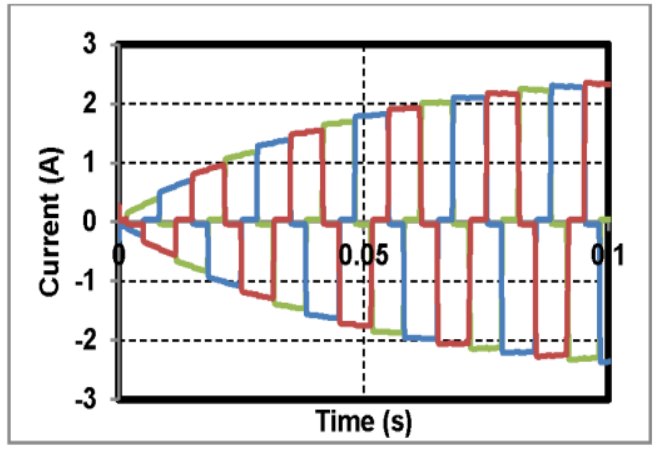

(a)

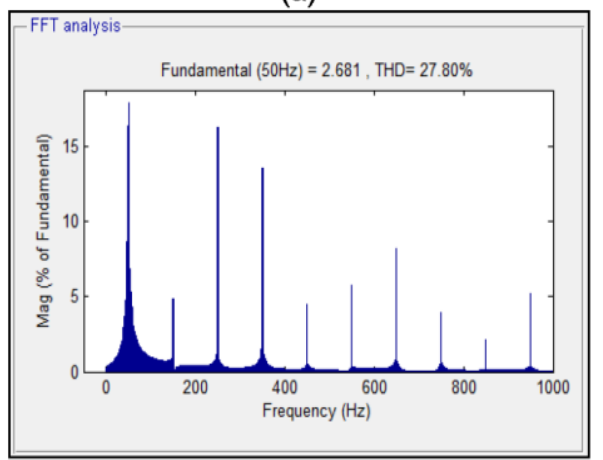

(c)

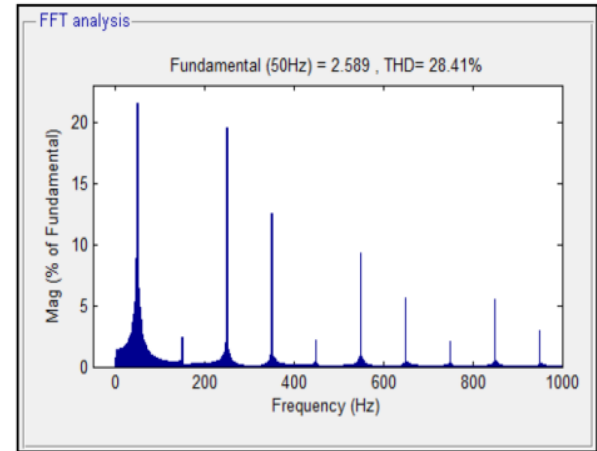

(b)

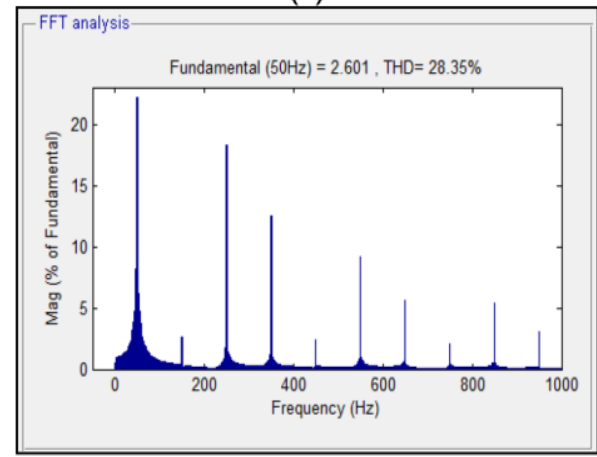

(d)

Figure 5. A system before the shunt active filter operation (a) Three phase current, (b) Total harmonic distortion phase $R\left(I_{R}\right)$, (c) Total harmonic distortion phase $S\left(I_{S}\right)$,

(d) Total harmonic distortion phase $\mathrm{T}\left(\mathrm{I}_{\mathrm{T}}\right)$

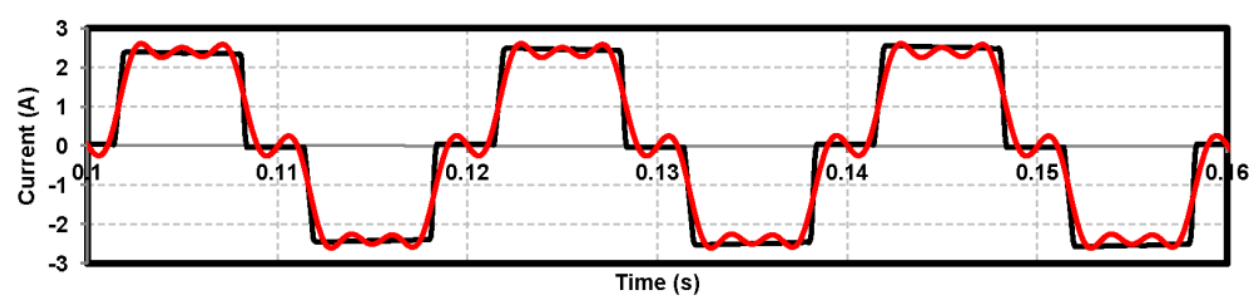

Figure 6. The Fourier Series approximations of I_R current

The FFT analysis shows that the three phases system has large a total harmonic distortion (THD) and the time domain plot also agrees with Fourier Series approximations. The Fourier Series approximations shows that the three phases system has a lot of harmonic frequency. This paper was proposed a shunt active power filter based on $P-Q$ theory. As an inverter, a dual level $\mathrm{H}$-bridge inverter (DLHI) and clamp diode multilevel inverter (CDMI) was used in this research.

\subsection{Performance Shunt Active Filter with dual level H-bridge inverter (DLHI)}

The performance shunt active filter with dual level $\mathrm{H}$-bridge inverter (DLHI) is shown in Figure 7. It is shown that before the shunt active filter operation, the source of current is highly rich in harmonics. After the shunt active filter starts the compensation process, the source is sinusoidal with phase $0^{\circ}, 120^{\circ}$, and $240^{\circ}$. A Powergui FFT Analysis Tools on Powergui Matlab Simulink is used to get the value of THD. The THD before the shunt active filter operation has $28.41 \%, 27.08 \%$, and $28.35 \%$. The THD after the shunt active filter with dual level $\mathrm{H}$-bridge inverter (DLHI) has $3.73 \%, 3.72 \%$, and $4.53 \%$. The THD value has conformity with the standard IEEE recommendations (THD $<=5 \%$ ). 


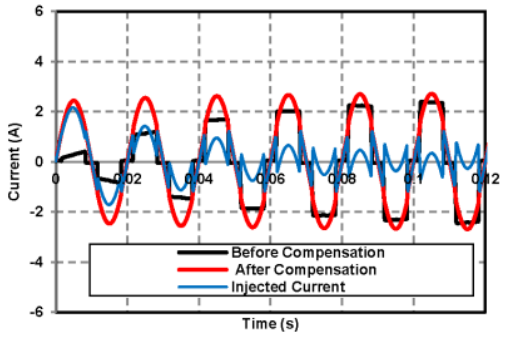

(a)

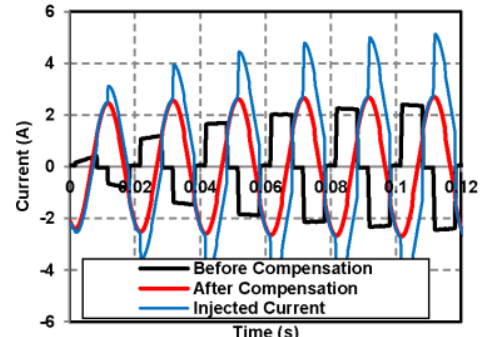

(b)

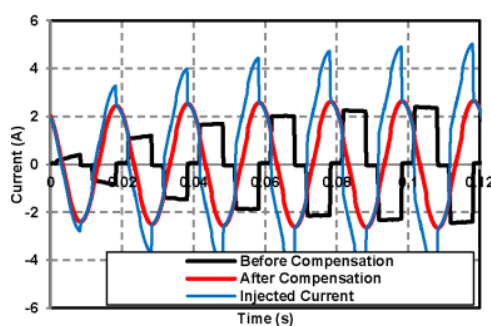

Figure 7. (a) The source current $\left(I_{R}\right)$ after and before compensation with injected current by dual level $\mathrm{H}$-bridge inverter (DLHI), (b) The source current $\left(\mathrm{I}_{\mathrm{S}}\right.$ ) after and before compensation with injected current by dual level $\mathrm{H}$-bridge inverter (DLHI), (c) The source current $\left(\mathrm{I}_{T}\right)$ after and before compensation with injected current by dual level $\mathrm{H}$-bridge inverter (DLHI)

\subsection{Performance Shunt Active Filter with clamp diode multilevel inverter (CDMI)}

The performance shunt active filter with a clamp diode multilevel inverter (CDMI) is shown in Figure 8. It is shown that before the shunt active filter operation, the source of current is highly rich in harmonics. After the shunt active filter starts the compensation process, the source is sinusoidal with phase $0^{\circ}, 120^{\circ}$, and $240^{\circ}$. The THD after the shunt active filter with clamp diode multilevel inverter (CDMI) has $1.91 \%, 1.93 \%$, and $1.91 \%$. The THD value has conformity with the standard IEEE recommendations (THD $<=5 \%$ ).

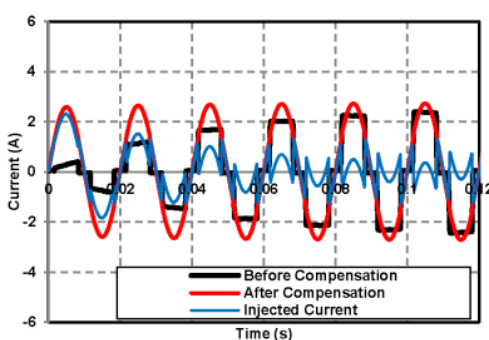

(a)

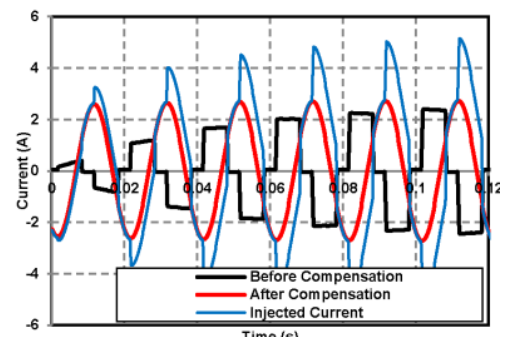

(b)

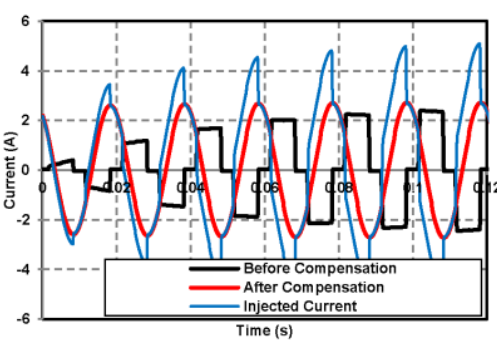

Figure 8. (a) The source current $\left(I_{R}\right)$ after and before compensation with injected current by clamp diode multilevel inverter (CDMI), (b) The source current $\left(\mathrm{I}_{\mathrm{S}}\right)$ after and before compensation with injected current by clamp diode multilevel inverter (CDMI),

(c) The source current $\left(\mathrm{I}_{\mathrm{T}}\right)$ after and before compensation with injected current by clamp diode multilevel inverter (CDMI) 
The result showed that active power filter with CDMI produced lower total harmonic distortion (THD) than active power filter with DLHI. The THD with DLHI and CDMI is lower than limits of IEEE harmonics standards. It is also shown that the proposed shunt active power filter has lower THD compared to another type of active power filter as shown in Table 4.

Table 4. The THD Value Compared to Another Type of Active Power Filter

\begin{tabular}{|c|c|c|c|c|c|}
\hline References & Systems & Controller & Inverter & $\begin{array}{c}\text { THD } \\
\text { before compensation }\end{array}$ & $\begin{array}{c}\text { THD } \\
\text { after compensation }\end{array}$ \\
\hline \multirow{3}{*}{$\begin{array}{l}\text { Ciprian } \\
\text { Balanuta, } \\
\text { et al } \\
\text { [6] }\end{array}$} & \multirow{3}{*}{$\begin{array}{l}\text { 3-phase } \\
300 \mathrm{~V} \\
50 \mathrm{~Hz}\end{array}$} & $\begin{array}{l}\text { Notch } \\
\text { control }\end{array}$ & & $19.76 \%$ & $5.58 \%$ \\
\hline & & P-Q Theory & $\begin{array}{l}\text { pulse width } \\
\text { modulation }\end{array}$ & $19.76 \%$ & $3.54 \%$ \\
\hline & & $\begin{array}{c}\text { Positive } \\
\text { Sequences }\end{array}$ & & $19.76 \%$ & $12.76 \%$ \\
\hline \multirow{4}{*}{$\begin{array}{c}\text { C L Anooja } \\
{[7]}\end{array}$} & 1-phase & \multirow{4}{*}{$\begin{array}{l}\text { PI controller } \\
\text { Fuzzy } \\
\text { controller }\end{array}$} & dual-level inverter & $15.5 \%$ & $8.39 \%$ \\
\hline & $230 \mathrm{~V}$ & & multi-level inverter & $15.5 \%$ & $7.10 \%$ \\
\hline & $50 \mathrm{~Hz}$ & & dual-level inverter & $15.5 \%$ & $5.68 \%$ \\
\hline & & & multi-level inverter & $15.5 \%$ & $4.47 \%$ \\
\hline \multirow{2}{*}{$\begin{array}{l}\text { Chennai } \\
\text { Salim } \\
{[8]}\end{array}$} & \multirow{2}{*}{$\begin{array}{l}\text { 3-phase } \\
220 \mathrm{~V} \\
50 \mathrm{~Hz}\end{array}$} & \multirow[t]{2}{*}{$\begin{array}{c}\text { Fuzzy } \\
\text { controller }\end{array}$} & $\begin{array}{l}\text { pulse width } \\
\text { modulation }\end{array}$ & $28.16 \%$ & $2.12 \%$ \\
\hline & & & $\begin{array}{l}\text { dual level H-bridge } \\
\text { inverter (DLHI) } \\
\text { [Inverter Model 1] }\end{array}$ & $\begin{array}{l}\text { Phase } R=28.41 \% \\
\text { Phase } S=27.08 \% \\
\text { Phase } T=28.35 \%\end{array}$ & $\begin{array}{l}\text { Phase } \mathrm{R}=3.73 \% \\
\text { Phase } \mathrm{S}=3.72 \% \\
\text { Phase } \mathrm{T}=4.53 \%\end{array}$ \\
\hline This work & $\begin{array}{l}\text { 3-phase } \\
220 \mathrm{~V} \\
50 \mathrm{~Hz}\end{array}$ & $\begin{array}{l}\text { P-Q Theory } \\
\text { combine } \\
\text { HPF }\end{array}$ & $\begin{array}{c}\text { clamp diode } \\
\text { multilevel inverter } \\
\text { (CDMI) } \\
\text { [Inverter Model 2] }\end{array}$ & $\begin{array}{l}\text { Phase } R=28.41 \% \\
\text { Phase } S=27.08 \% \\
\text { Phase } T=28.35 \%\end{array}$ & $\begin{array}{l}\text { Phase } R=1.91 \% \\
\text { Phase } S=1.93 \% \\
\text { Phase } T=1.91 \%\end{array}$ \\
\hline
\end{tabular}

\section{Conclusion}

A shunt active power filter based on $\mathrm{P}-\mathrm{Q}$ theory with dual level $\mathrm{H}$-bridge inverter (DLHI) and clamp diode multilevel inverter (CDMI) was design, modified, and analyzed. This shunt active power filter was applied to 3 phase power system with a voltage of $220 \mathrm{~V}$ and frequency of $50 \mathrm{~Hz}$. The simulation model was constructed using Simulink MATLAB. The simulation result showed that active power filter with CDMI produced lower total harmonic distortion (THD) than active power filter with DLHI. The two cases studied in conformity with the standard IEEE recommendations (THD $<=5 \%$ ). It is also shown that the proposed shunt active power filter has lower THD compared to another type of active power filter.

\section{References}

[1] Ahuja, Rajesh KC, Aasha. Hysteresis Control for Current Harmonics Suppression Using Shunt Active Filter. International Journal of Advancements in Research and Technology (IJART). 2012; 1(6): 1724.

[2] Akagi H. New Trends in Active Filters for Power Conditioning. IEEE Transaction on Industrial Applications. 1996; 32(4): 1312-1322.

[3] O Abdelkhalek. A Novel Theory Of Reference Harmonic Current Identification Based On The Per Unit System Used For The Active Filters. Journal of Electrical \& Electronics Engineering (JEEE). 2008; 8(2): 747-757.

[4] Ciprian B, Gelu G. Three-Phase Active Power Filter Control Using Notch Instantaneous P-Q Theory and Positive Sequence Method. Scientific Bulletin of the Electrical Engineering (SBEE). 2011; 3(17): 11-17.

[5] Karuppanan PV. Adaptive-Fuzzy Controller Based Shunt Active Filter for Power Line Conditioners. TELKOMUNIKA. 2014; 9(2): 203-210.

[6] S Narmada. Simulink Model of Elimination of Harmonics By Using Multilevel - Inverters Through Hysteresis Control. International Journal of Advanced Trends in Computer Science and Engineering (IJATCSE). 2013; 2(1): 286-292.

[7] CL Anooja, N Leena. Single Phase Shunt Active Filter with Fuzzy Controller for Harmonic Mitigation. International Journal of Scientific \& Engineering Research (IJSER). 2013; 4(9): 445-451.

[8] Chennai S, Benchouia MT. Fuzzy Controller for Harmonic Currents Compensation under Non-Ideal Voltage Conditions. International Journal on Electrical Engineering and Informatics (IJEEI). 2014; 6(2); 342-358. 
[9] Krishna VS, Priyank B. Matlab Simulation of Single Phase Shunt Active Filter Based on PQ Theory. International Journal of Advances in Electrical and Electronics Engineering (IJAEEE). 2012; 2(3): 349-357.

[10] T Himabindu. Performance of Single Phase Shunt Active Filter Based on P-Q Technique Using Matlab/Simulink. International Journal of Engineering Research \& Technology (IJERT). 2012; 1(9): 15

[11] G Vijayakumar, R Anita. Real time digital simulation of shunt active filter for mitigation of current harmonics with P-Q theory. Scientific Research and Essays (SRE). 2013; 8(26): 1239-1251.

[12] Priyank RB, Pinkal JP. Shunt Active Filter: PSIM based Simulation and analysis using $P-Q$ theory. Proc. of the International Conference on Science and Engineering (ICSE), 2011: 90-93.

[13] Pradeep K. Simulation of Three-Phase Three-Wire Active Power Filter using p-q Theory. International Journal of Innovative Research in Electrical, Electronics, Instrumentation and Control Engineering (IJIREEICE). 2016; 4(3): 5-8.

[14] M Priya, Uthaya, Suresh B. Simulation Results of a Shunt Active Power Filter Using P-Q Theory Power Components Calculations. International Journal of Advance Research in Computer Science and Management Studies (IJARCSMS). 2014; 2(2): 250-254.

[15] W Gunawan, et al. Design of triple-band bandpass filter using cascade tri-section stepped impedance resonators. Journal of ICT Research and Applications. 2016; 10: 43-56.

[16] W Gunawan, et al. Multiband bandpass filter (BPF) based on folded dual crossed open stubs. International Journal of Technology. 2014; 5: 32-39.

[17] F Teguh, et al. Multiband RF low noise amplifier (LNA) base on multi section impedance transformer for multi frequency application. International Journal of Applied Engineering Research. 2016; 11: 3478-3483.

[18] G Wibisono, T Firmansyah. Design of dielectric resonators oscillator for mobile WiMAX at 2,3 $\mathrm{GHz}$ with additional coupling N/4. IEEE Region 10 Conference TENCON. 2011: 489-493. 